EPOS, XIV (1998), págs. 493-513

\title{
PROBLEMAS DE PERIODIZACIÓN Y CARACTERIZACIÓN EN HISTORIA DE LA LENGUA LITERARIA ESPAÑOLA (II) ${ }^{1}$
}

Francisco Abad

UNED

\section{RESUMEN}

El presente escrito argumenta en favor de prolongar el estudio de la historia de la lengua (literaria) española a partir de 1681, que es la fecha hacia la cual suele detenerse el análisis en los panoramas de conjunto; tal preterición se debe en parte a la condena que la historingrafia conservadora ha hecho de nuestros siglos XVIII y (sobre todo) XIX.

Se propone y concreta una periodización corta de la trayectoria del idioma, y el autor retoca algunas fechas dadas por él con anterioridad, y caracteriza a modo de ejemplo algunos hechos ocurridos en la historia de la lengua y del lenguaje literario españoles.

1 Continuamos las reflexiones que ya hicimos en una primera parte, que está en Revista de Filología Románica de la Univ. Complutense, $\mathrm{n}^{\mathrm{Q}} 15$, 1998; pueden verse además las «Cuestiones en torno a la Historia de la lengua literaria española», que damos en Apéndice de la tercera edición de Curso de Crítica Literaria. Addenda, Madrid, Editorial de la UNED, 1998, pp. 107-128. Asimismo para los aspectos léxicos y lexicográficos de la historia moderna del idioma cfr. las Cuestiones de lexicología y lexicografia, Madrid, Editorial de la UNED, 1997, de la que hay segunda edición reformada (1999). 
Se insiste también en la impronta de la acción normativa y niveladora de la Real Academia.

\section{ORfGENES DEL ESPAÑOL}

De la *Historia de la lengua española que escribió Menéndez Pidal hasta llegar a 1713 están publicados algunos capítulos y fragmentos, uno de los cuales aborda el período «De Alfonso a los dos Juanes», que trata evidentemente del rey Alfonso X, de don Juan Manuel y de Juan Ruiz.

El propio don Ramón Menéndez Pidal hablaba de los «orígenes tardíos del idioma» refiriéndose al estado lingüístico peninsular «hasta el siglo $\mathrm{XI}$ », pero en verdad estos «orígenes» del idioma habría que retrasarlos hasta el siglo XIII, cuando el idioma se emplea para todos los usos y posee así vitalidad universal en cuanto código comunicativo; las lenguas se caracterizan por tener ciertamente vitalidad o vigencia para todos los usos, y es lo que ocurre con el castellano desde ese siglo XIII.

Lo anterior al empleo del idioma para los más variados usos literarios o no, proponemos considerarlo como perteneciente a sus «orígenes»: la lengua se manifiesta en cuanto tal a lo largo de la mencionada centuria del XIII. El cultivo literario de la prosa también data del Doscientos y según exponía el maestro gallego-asturiano «no produjo obras verdaderamente notables sino en la corte de [...] Alfonso X».

Juan Luis Alborg ha escrito unos párrafos en que en realidad se hace eco -aunque no lo advierta- de don Jaime Oliver, párrafos que exponen pedagógicamente lo ocurrido con el idioma castellano en el Doscientos:

Se hablaba en romance, pero se seguía escribiendo en latín porque sólo a esta lengua se le reconocía dignidad para redactar los documentos, las historias, los libros gravemente doctrinales. [...] Se imponía pues el retorno a la unidad linguíística [...] porque sólo con un idioma único podía hacerse la divulgación eficaz de todo[s los contenidos], [...] siguiendo en esto la natural secularización de la cultura que poco a poco se venía imponiendo en toda Europa. La consecución de esta unidad idiomática es la gran empresa literaria del siglo XIII.

Ya decimos que cualquier lector de don Jaime Oliver reconoce en las presentes líneas una casi transcripción de una página suya, pero no es tal hecho el que importa sino el de la relevancia de la centuria del Doscientos en la historia de la lengua (literaria) española. 
Francisco López Estrada ha escrito un capítulo sobre «Lenguas y literaturas» en el Tomo XI de la llamada Historia de España Menéndez Pidal de Espasa Calpe (1995), y en el mismo se ocupa de «Alfonso X y el nacimiento de la prosa vernácula»; tal tomo XI se encuentra dedicado a «La cultura del Románico», y resulta extraño que para la segunda mitad del Doscientos se siga hablando aún de «Románico»: el rey Alfonso pertenece a la época del «Gótico» en la cultura española, mientras el «Románico» se remonta a centurias más atrás. De manera muy elemental y pedagógica, hay que decir que la época del Románico es la de los siglos XI y XII, y la del «Gótico» la de los siglos XIII, XIV y XV.

En cualquier caso la lengua (literaria) castellana medieval se nos ofrece articulada en épocas que según entendemos personalmente son las siguientes:

Desde después de 1160, fecha del Cid (Horrent)

1215-1250: Época de Berceo

1250-1284: Epoca de Alfonso X

1284-h.1320: Época de la herencia alfonsí

h.1320-1351: Epoca de Alfonso XI

1351-1383: Época de Don Sem Tob

1383-1417: Epoca del Canciller Ayala

1417-1454: Epoca de Juan II: Santillana, Mena, ...

1454-1492: Epoca de Enrique IV y de comienzos de los Reyes Católicos.

Hemos retocado la cronología de las dos últimas épocas respecto de versiones anteriores nuestras de esta periodización: consideramos así que acierta Menéndez Pidal al mantener que hay un período que «viniendo de los últimos años del siglo [XV], llega hacia 1525». Efectivamente aunque el transcurrir lingüístico sea un continuo, la codificación de un idioma mediante diccionarios y gramáticas, las innovaciones de estilo, etc., señalan discontinuidades que resulta adecuado tener presentes.

Respecto de la «Época de Berceo» por ejemplo, cabe apuntar que creemos que asimismo acierta don Ramón cuando establece que «á la mitad del siglo XIII [...] se escribieron el Alexandre, el Fernán González y el Apolonio».

\section{Siglo de Oro y Edad de Plata}

Existe una valoración de las primeras centurias modernas en la literatura española que podemos verla recogida y difundida por el propio Juan Luis Alborg, y que debemos conocer y luego glosar. 
A propósito del Cuatrocientos destaca el presente autor lo que tuvo de necesaria introducción a los siglos posteriores: «El siglo XV - escribe- prepara y hace posible la formidable explosión cultural de los dos siglos inmediatos que constituyen la Época de Oro de las letras españolas, y de las cuales esta centuria es la incompleta pero necesaria y fecunda introducción».

Nos encontramos pues ante un necesario requisito para la llamada «Época de Oro» de las letras castellanas, asimismo denominada por Alborg como «Siglo de Oro», del cual escribe:

Las centurias anteriores pueden considerarse como una época de formación y de tanteos. [...] Con el siglo XVI en cambio asistimos a una floración que alcanza todos los géneros y que se produce de una manera orgánica, coherente, ininterrumpida [...] para cuajar en los productos más notables y originales en toda la historia de nuestra cultura. [...] En el [siglo XVII] se dan los caracteres más típicos y personales de nuestras letras.

Tras los necesarios tanteos, ocurre pues la eclosión literaria que tradicionalmente siempre se ha señalado que va de Garcilaso a Calderón; Alborg reorienta sus propias palabras cuando en otros párrafos establece que «la segunda mitad del XVI» no parece tener «menores derechos a ser calificada de nacional» que la síntesis estética y de ideas del Barroco.

Nuestro crítico difunde por tanto la idea de que la literatura nacional propiamente dicha es la de la época de los Felipes, la que va de Felipe II a Felipe IV más o menos, y esto supone una valoración y una toma de postura.

La visión más convencional y a veces conservadora de la historia de España se remonta siempre en efecto (con unas $u$ otras diferencias interpretativas), al denominado Siglo de Oro, y ya vemos cómo la Historia de la literatura española de Juan Luis Alborg propugna en su primer y su segundo volúmenes que lo típico, notable y original de la literatura nacional es la época de Felipe II y del Barroco. Existe otra mirada hacia nuestro pasado, que destaca asimismo la denominada «Edad de Plata» del mismo (1860/68-1936) y más ampliamente toda la época liberal (1808/1833-1936): Larra, Galdós, Clarín, la Pardo Bazán, Menéndez Pelayo, el 98, Menéndez Pidal, Américo Castro y Dámaso Alonso, Juan Ramón y Ramón Gómez de la Serna, el Veintisiete, no suponen menos relieve y originalidad que bastantes autores del XVI y XVII, y desde luego sin ellos no cabe hablar de cultura nacional española. Incluso podemos remontarnos al tercio último del Setecientos, para incluir en la presente serie a Jovellanos y a Goya.

Se trata por tanto de no reducir el pasado de esplendor de las letras y la cultura española al Siglo o Edad de Oro, y se trata así de incorporar a 
la conciencia cultural y cívica de los españoles una visión de lo mucho y relevante ocurrido en el llamado "siglo" liberal español (1808/18331936).

Ocurre ciertamente que ha existido y por inercia o falta de reflexión todavía existe, una desestimación explícita de nuestro Ochocientos y primer tercio del siglo XX; en otros escritos hemos dado muestras textuales de esto que decimos.

Excurso: la desestima del Pasado liberal y de Menéndez Pidal

La idea a la que queremos venir a parar es la de que junto al estudio de la Historia de la lengua (literaria) medieval y clásica, ha de hacerse también el del idioma moderno posterior a 1713. Don Ramón dejo su análisis —en la aludida ${ }^{*}$ Historia...- en un capítulo XII denominado «Época barroca, 1610-1713», pero no evidentemente por ningún rechazo a su propia época, sino en primer lugar porque todo autor detiene el estudio en una cierta distancia cronológica, para asi poder disponer de alguna perspectiva; puede decirse además que $\mathrm{Me}$ néndez Pidal participa de un nacionalismo que exalta las glorias y esplendores del pasado y que ello le hace estar prendido de los tiempos medievales y áureos, pero en ningun caso rechaza el Ochocientos ni el primer tercio del siglo $\mathrm{XX}$; otros autores exaltan el pasado áureo y a la vez condenan los tiempos contemporáneos.

Por la inmediatez temporal con el Setecientos y el Ochocientos y por una impregnación nacionalista atenta al esplendor del pasado, don Ramón Menéndez Pidal no se ocupó de hacer la Historia de la lengua más acá de 1713 (y por las propias limitaciones de toda vida humana, aun la más fecunda); en términos generales que ya no afectan a lo pidalino hay que decir que el análisis y estimación del siglo XVIII y sobre todo del llamado «siglo» liberal (1808/18331936) ha estado preterido por la condenación explícita que el pensamiento más conservador hace de tales centurias. Al maestro gallego-asturiano, que constituye una figura de mucho relieve en parte del XIX y del XX y resulta ser por tanto un objeto historiográfico, asimismo se le ha rechazado más o menos y con palabras explícitas.

Por ejemplo Rafael Calvo Serer publicaba en 1952 y otra vez en 1955 la Teoría de la Restauración, y en ella se hacía eco de un párrafo de Guillermo Díaz Plaja en el que se estaba claramente en contra del espíritu del Centro de Estudios Históricos y de la escuela pidalina; hemos buscado directamente tal pasaje en el volumen de Díaz Plaja «La ventana de papel» (1939), y encontramos en efecto las siguientes indicaciones: 
La reacción «izquierdista»: [...] Castro, Montesinos, tienden (sic) a valorar los ejemplos de libertad de pensamiento en España, pretendiendo presentar a nuestros escritores más insignes como ejemplos de conciencias libres o vacilantes más o menos encubiertas. La cantidad de proselitismo que esta actitud encierra es extraordinaria. Los recientes estudios sobre Cervantes, Erasmo y los Valdés son ejemplos paladinos. Sería muy interesante un estudio que precisara la concatenación de estas actitudes con las que adopta frente al catolicismo la generación del noventa y ocho y la de sus inmediatos seguidores. [...] Así la tesis de Castro según la cual Cervantes sería un astuto disimulador de sus ideas no es sino el reflejo de una voluntad más o menos consciente de transformar el espíritu de la historia de España a gusto de determinada ideología.

Nos encontramos ante el rechazo de lo que se denomina «ideología izquierdista» en la interpretación del pasado español y lo que se supone su afán de proselitismo: es una idea que Rafael Calvo Serer ilustra con el testimonio de Guillermo Díaz Plaja y que hace suya; con palabras ya propias dice el prof. Calvo que «la idea rutinaria de lo español» que cuaja en la República de profesores de 1931 «ha sido influida" por los escritores Ortega y Gasset, Luis Araquistáin, Manuel Azaña, Salvador de Madariaga o Fernando de los Ríos.

Tenemos pues cómo se minusvalora la obra crítica del Centro de Estudios Histórico pidalino, y se rechaza de esta manera - apuntando por elevacióntoda la actividad intelectual de los estudiosos liberales. El Ochocientos y el primer tercio del siglo $\mathrm{XX}$ resultan de esta manera preteridos.

Una misma orientación interpretativa se encuentra en el volumen de Florentino Pérez Embid Ambiciones españolas (1953 y segunda edición en 1955). Este autor proclama abiertamente cómo los siglos últimos de la trayectoria española no se corresponden con su supuesta identidad de esencias inmutables:

El presente desde hace siglos —exclama-, está en desacuerdo con la eterna metafísica de España. En 1936 los españoles se lanzaron por fin a cortar la carne propia con la trágica cirugía que habían hecho inevitable los teóricos de la España antiespañola.

Se nos dice que existe una «eterna metafísica» representada por ejemplo en los sucesos de 1936, y que de ella nos han desviado los teóricos o intelectuales; se trata en realidad de «un paréntesis de tres siglos», según mantiene Pérez Embid, esto es, de un paréntesis «que se abrió en Westfalia» y que en la época de Franco se trataba de cerrar. 
La cronología 1648-1939 supone en esta interpretación un todo de tres centurias en las que España ha sido llevada a alejarse de su «eterna metafísica». Florentino Pérez Embid señala programáticamente un doble punto de partida para «continuar la historia española» tras la guerra civil: «superación del complejo de inferioridad que inician los españoles tundidos por la realidad de la derrota en 1648, y definitivo ajenamiento de las ideas que rigen el mundo liberal constituido fundamentalmente a partir de la revolución europea de 1848 ».

Ocurre así una desestimación y un rechazo de los siglos últimos y en concreto del Ochocientos; tal desestimación que testimonian las äfirmaciones de nuestro autor ha coadyuvado sin duda a la falta de análisis de estos siglos más recientes, lo que ha alcanzado también a los estudios filológicos.

Por último vamos a tener presente otro libro de Rafael Calvo Serer, Polftica de integración (1955). Calvo menciona ahora a «Menéndez Pidal y sus seguidores», quienes «pretenden presentarnos otra vez en el mismo plano de igualdad» las llamadas dos Españas, y menciona también a Américo Castro y Julián Marías, quienes «han destacado en estos últimos tiempos los valores positivos de esa otra España» progresista y no tradicional; Calvo sin embargo enfatiza sobre «la evidente continuidad ortodoxa, la gran tradición de nuestro país, incluso de 1808 a 1936 ». Menéndez Pidal mantiene -repite Rafael Calvo Serer- una «interpretación igualitaria de las dos Españas», lo que le reprocha, y está unido a «su labor universitaria de sabor institucionista» y además «quebranta gravemente la interpretación católica de la historia española». Estamos pues ante una concepción monolítica del pasado que identifica lo español con lo católico, ante dos Españas que no pueden quedar tratadas con igualdad porque una es ortodoxa y la otra no.

En definitiva encontramos un descontento con o condena de la España -en los términos más amplios- posterior a 1648, y muy en particular de la posterior al segundo tercio del Ochocientos y hasta 1936; tal condena ha llevado en las ciencias humanas a la preterición en el estudio de los siglos más modernos, y en particular ello ha ocurrido en lo filologico.

Queremos decir que importa la Historia de la lengua (literaria) referida al Cid o a Juan Ruiz, o a Cervantes, pero que no por eso hay que dejar de lado a Jovellanos, o a Galdós, etc.; nuestra dedicación profesional a la Crítica Literaria creemos que no hace ocioso que nos hayamos preocupado por cómo se ha llegado a la preterición del «siglo» liberal español.

El LeNGUAJE LITERARIO ENTRE NebriJa y Gracián

Según queda apuntado el último capítulo escrito por don Ramón de su *Historia de la lengua española es el XII, dedicado a los tiempos del Barroco; 
tal capítulo está publicado desde 1986, en que apareció formando parte precisamente del Tomo XXVI/2 de la Historia de España Menéndez Pidal (en 1991 ha aparecido asimismo en volumen exento:La lengua castellana en el siglo $X V I I)$.

Este capítulo lleva el rótulo que ya hemos avanzado «Época barroca, 1610-1713", y de él hemos de partir si nos proponemos continuar en algún sentido la Historia que el maestro dejo inacabada; en realidad puede decirse que lo referido a 1713-1973 se halla también cubierto en parte mediante una exposición de conjunto, sumando sucesivos capítulos de los volúmenes de Rafael Lapesa Historia de la lengua española (1981), El español moderno y contemporáneo (1996) y Léxico e historia. Diccionarios (1992), más varios de sus artículos dedicados al análisis de diferentes estilos literarios. Ciertamente si a lo publicado del texto de don Ramón - y en su día a todo el texto que dejó él, cuando haya sido editado- sumamos las páginas que indicamos de Lapesa, encontramos en sus líneas generales una Historia de nuestra lengua sólida e instructiva, aunque como todo lo humano sujeto a ampliación y a rectificaciones específicas (Menéndez Pidal no pudo conocer el formalismo crítico-literario, y sin tal marco teórico no pudo advertir lo que de artificio se da a veces en los autores literarios).

En el conjunto de los siglos XVI y XVII el maestro gallego-asturiano delimitaba una primera época - según queda advertido- desde los últimos años del siglo XV hasta hacia 1525, y luego el "período de Garcilaso», el «período de los grandes místicos» (1555-1585), el "período de Cervantes y Lope de Vega» (1585-1617), y la «época barroca»; esta última la subdividía a su vez en los años de «esplendor de la literatura barroca» (1610-1635), y en los años de «Gracián [y] postrimerías de Calderón» (1637-1681). Nuestro autor prolonga el período de Cervantes hasta su muerte, y antes —desde «1610»- considera establecida ya la época «barroca»: el año coincide con el llamado «segundo estilo» de Góngora, el presente en la oda «A la toma de Larache», la Fábula de Polifemo y Galatea o las Soledades; Menéndez Pidal advierte así que en los años diez del Seiscientos coexisten el estilo característico de Cervantes y el de Góngora, mientras hoy tendemos a adelantar algo la cronología del Barroco. El mencionado Juan Luis Alborg subraya efectivamente cómo «de toda la producción poética de Góngora la obra central y más típicamente gongorina son las Soledades», composición en la que la Naturaleza «está rabiosamente trocada en literatura, radicalmente estilizada, convertida en metáforas espléndidas», y ello a diferencia del sentimiento de la Naturaleza de Garcilaso o fray Luis de León.

Don Ramón no llegó a ocuparse - al abordar los años posteriores a 1637- de obras con las que deberemos empezar si pretendemos continuar su 
trazado historiográfico: se trata de La vida y hechos de Estebanillo González, hombre de buen humor, de la Parte segunda del Sarao, y entretenimiento honesto de doña María de Zayas, o de El Criticón, etc. A partir del analisis de por ejemplo estos textos, el relato deberá seguirse en el 1681 en que en realidad lo dejó Menéndez Pidal.

Nunca lamentaremos bastante que el maestro de maestros no ultimase los capítulos que faltaban de su *Historia de la lengua española, pero quizá era inevitable psicologicamente: se trataba de tiempos bastante cercanos en los que él participaba de una u otra manera (los propios recuerdos y vivencias familiares, la pertenencia a la Academia fundada en el XVIII, etc.), y sin un mínimo distanciamiento y sin perspectiva no resultaba posible embarcarse en el estudio; además todo estudioso vuelve según van pasando los años a la temática con los que más íntimamente se ha identificado, y en el caso de don Ramón tal temática era acaso la de la épica y el romancero, y la del sentido de la historia española (de ahí el volumen antilascasiano).

Por nuestra parte los subperíodos sucesivos de la lengua literaria en los siglos XVI y XVII proponemos entenderlos así:

1492-1526: Época de Nebrija y de comienzos de Carlos V

1526-1555: Epoca de Garcilaso y del erasmismo español

1555-1585: Epoca de los grandes místicos

1585-1616: Época de Cervantes, Góngora, el primer Lope, ...

1616-1647: Epoca del segundo Lope, Quevedo, el primer Calderón, ... 1647-1681: Epoca de Gracián.

Hemos retocado asimismo alguna de las fechas que simbolizan unos $u$ otros períodos, respecto de versiones anteriores que hemos dado; solo subrayaremos que de acuerdo con el espíritu de lo dicho por Menéndez Pidal, destacamos ahora el año 1526 que simboliza la revolución poética de Garcilaso, revolución en las formas métricas y en los contenidos. Igualmente destacamos el año 1647 porque entonces y en 1648 publica Gracián las versiones definitivas de libros anteriores suyos, y desde 1651 aparecerá El Criticón: nos encontramos ciertamente en la «época de Gracián».

Menéndez Pidal indicaba que la obra de Juan de Mena es una de las que el Cuatrocientos lega al siglo XVI, pero este apunte debe completarse para poder entender la ruptura en las formas poéticas que lleva a cabo Garcilaso: asimismo el legado del Cuatrocientos al Quinientos estaba integrado por la poesía de cancionero. Rafael Lapesa ha notado la diferencia poética que va de tal poesía de cancionero a la poesía italianizante, pero ya decimos que Garcilaso está en contra en su escribir, tanto de la poética de los cancioneros como de 
la poética de Juan de Mena; Lapesa establece bien parte de los hechos, y dice así en un párrafo que ha de tenerse presente:

La poesía de los cancioneros castellanos era un producto artístico muy elaborado y muy vario: graciosa y ligera, llana y realista, abstracta y densa según los casos, contaba con un metro dúctil, el octosílabo, capaz de plegarse al tono requerido. [...] Los metros que introducían [Boscán y Garcilaso] eran lentos, reposados, menos pendientes que el octosílabo de la rima acuciadora; [...] era el ritmo adecuado para la exploración del propio yo en detenidos análisis, y para expresar el arrobo contemplativo ante la naturaleza.

Estamos pues ante una poética de verso largo, de la melodía y no del sonido, y que se oponía a la herencia cuatrocentista, tanto la de cancionero como la de Juan de Mena. En el presente contexto se ha de entender aquello dicho por Lope de Vega:

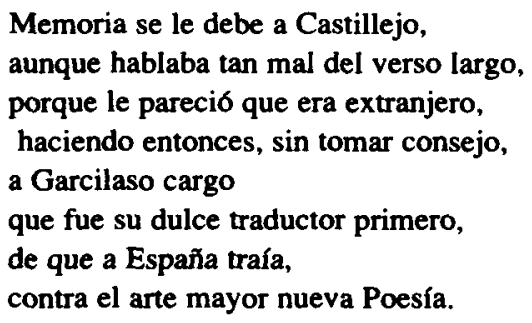

En otros escritos nos hemos referido ya a estas cuestiones; se trata en última síntesis de que con Garcilaso estamos ante un verso largo que posibilita el despliegue discursivo y que se halla «en contra del arte mayor», es decir, en contra de un verso que en realidad era corto (pues estaba partido en hemistiquios) y era a la vez sonoro pero no melodioso. El contenido de sentimiento de la Naturaleza y no sólo mera temática del paisaje en el poeta toledano, ya lo advirtio por ejemplo Emilio Orozco; por otro lado la exploración del yo es muy nítida en Garcilaso.

En definitiva debemos hacernos cargo de que la Historia de la lengua de Menéndez Pidal -que era en buena parte una Historia del idioma literario español-, quedó escrita por su autor hasta llegar a 1681, si bien no pudo atender en sus últimos pasajes (estamos ante una obra inacabada y póstuma), al Gracián de El Criticón o a algún texto más de interés. Para acabar a don Ramón quien se proponga completar su trabajo deberá situarse en ese 1681 . 


\section{LAS ÉPOCAS DEL ESPAÑOL MODERNO}

Desde 1681 hasta nuestros días transcurren unos tres siglos y un tercio, y diez épocas en la historia del idioma: cada época o período estimamos que dura alrededor de un tercio de siglo, el mismo tiempo que afecta a todas las manifestaciones humanas y en que la vida toda conserva un perfil propio diferenciado; cada tercio de siglo más o menos la vida cambia, acostumbran a decir incluso informalmente los mejores historiadores.

Delimitamos personalmente estas épocas linguiísticas en la historia del español: 1681-1713 (Antonio de Solís, los novatores); 1713/26-1741 (la Real Academia, Feijoo, Luzán); 1741-1771 (el Padre Isla, don Ramón de la Cruz); 1771-1803 (Cadalso, Jovellanos, Meléndez, Moratín); 1803-1843 (Larra, Espronceda); 1843-1874 (Zorrilla, Bécquer); 1874-1902/1904 (Galdós); 19041939 (Valle-Inclán, Ortega y Gasset, García Lorca y Luis Cemuda, etc.); 19391973; 1973- h. 2000.

Con el establecimiento de la Academia creemos que la periodización debe estar atenta al Diccionario y la Gramática o la Ortografía de la Corporación, que introducen ciertamente discontinuidades normativas en el uso de la lengua; por supuesto debe tenerse presente asimismo la historia literaria, y de resultas de lo uno y lo otro hemos retocado también las fechas que habíamos dado ya en otras ocasiones: ahora todas están referidas a alguna acción normativa de la Academia, si bien destacamos por igual el gran esplendor literario que se produce en 1902 y se continúa ininterrumpidamente hasta la guerra civil. En su tesis doctoral sobre el léxico dieciochista hasta 1760, Pedro Álvarez de Miranda arranca de 1680 , y en efecto desde hacia ese año asistimos a nuevas realidades que deberemos tener presentes al estudiar los períodos del español peor conocidos: los diez más cercanos a nosotros. La actual época que hacemos nacer en 1973 terminará hacia el año 2000 (quizá un poco después), con la publicación de una nueva edición del Diccionario académico y ojalá también de la Gramática.

El paso de la pronunciación medieval a la moderna se generaliza en la segunda mitad del Quinientos e inicios del Seiscientos, pero otros aspectos del idioma adquieren relevancia más tarde, e historiográficamente habrán de tenerse presentes; ya hemos aludido a la acción normativa de la Academia. En su Formación e historia de la lengua española de 1943, Rafael Lapesa escribía unas palabras que sugieren algunas cosas de las que ha de analizar el historiador de la lengua española moderna:

Con las transformaciones experimentadas a fines del siglo XVI por las consonantes era necesario un reajuste [en las costumbres orto- 
gráficas]. La Academia fue regularizando la ortografía hasta que a principios del siglo XIX se generalizó la que hoy empleamos. Estabilizada la pronunciación, reglamentada la gramática y sujeta a normas rigurosas la ortografía, los cambios lingüísticos del español moderno son menores que en otras épocas. [...]En contraste con la mayor fijeza del sistema lingüístico es muy activa la renovación del léxico, e incesante la creación estilística.

Desde 1726 se abre por tanto una nueva gran época en la trayectoria de la lengua, la del «español moderno»: el análisis habrá de tener en cuenta la historia de la ortografía, el léxico y la lexicografía, los estilos literarios, la norma gramatical, el nombre del idioma - no atendido por Amado Alonso desde mitad del Setecientos- , ... Es una manera distinta en parte de hacer Historia de la lengua que habrá de dar cuenta de lo sucedido desde los años del llamado Diccionario de Autoridades, si bien para completar el conjunto puede remontarse a lo posterior a Calderón (1681). Las últimas nueve o diez épocas últimas del idioma son acaso las peor entendidas en una visión de conjunto.

\section{Sobre la ACademia y SObre Moratín}

La obra primera de la Academia fue el Diccionario de la lengua castellana conocido como Diccionario de Autoridades, y en el mismo estaba incluido un «Discurso proemial de la orthographia de la lengua castellana» ${ }^{2}$. En general sobre el trabajo inicial académico ha escrito esta información -que luego comprobaremos en las fuentes- - don Emilio Cotarelo:

La Academia Española, fundada en 1713, [...] empez6 por producir un libro, el libro capital de todo pueblo: el catálogo de su idioma. [...] Desde la primera acta [...] señaló ya el número crecidísimo de buenos autores de todos tiempos en quienes había de buscarse no sólo las voces, sino sus verdaderas significaciones y acepciones. Y esta lista fue aumentando sin interrupción. [...] Terminado el Diccionario pensó la Academia en dar al público una buena y completa Gramática. Pero había una parte, la principal de ella por su aplicación práctica,que era de la mayor urgencia a causa de la anarquía [...] en cuanto a la manera de escribir las palabras. [... Al fin] salió a luz en 1741 la primera Ortografía que publicó la Academia. [...] En tanto siguió ela-

2 Una noticia de la trayectoria de la labor lexicográfica académica puede encontrarse en las Cuestiones de lexicologí... 
borándose con mucha lentitud y suspensiones que hoy nos parecen inexplicables la Gramática, [cuya] última redacción y arreglo fué obra del académico secretario don Juan Trigueros.

Cotarelo advertía además algo que deberá establecerse en detalle: la superioridad de la Gramática de la lengua castellana académica respecto de la inmediatamente anterior de fray Benito de San Pedro y respecto a Gayoso, etc.

Quizá han sido las sucesivas ediciones del Diccionario empero las que han tenido mayor acción normativa y niveladora del idioma, pues el Diccionario es la obra académica más consultada; según queda dicho el establecimiento de la Real Academia incide en la trayectoria del idioma y ha de tenerse siempre presente al hacer la Historia de la lengua española posterior a 1726: las sucesivas acciones normativas académicas suponen en principio otras tantas discontinuidades en el hacerse de la lengua, y de lo ocurrido en realidad en cada caso habrá de dejarse constancia.

Don Emilio Cotarelo aludí asimismo ( tenemos a la vista como seguramente se habrá advertido su «Discurso acerca de las obras publicadas por la Real Academia Española» de 1928) a la publicación por parte de la Corporación, luego de dos siglos de haber sido fundada, de un Diccionario manual e ilustrado; se trata, en palabras autorizadas de nuestro autor, de

un compendio en el que se pusiesen nada más que la definición de las palabras comunes para uso de las personas poco instruídas y de los extranjeros, pero en el que figurasen también otras voces que aunque usadas, no habían entrado aún en el Diccionario, ya por demasiado nuevas, por incorrectas o por constituír verdaderos extranjerismos innecesarios en la mayor parte de los casos.

Según decimos estas palabras tienen gran valor testimonial en cuanto autorizada exposición de los designios de la Academia que hizo por fin - tras haberlo pensado desde hacia 1814 un Diccionario manual; este Diccionario suponía asimismo la incorporación de muchos grabados que ilustraban acerca de objetos complicados o no fáciles de explicar con palabras.

Todo esto - la edición del Diccionario manual e ilustrado de la lengua española-ocurría en 1927, pero ya en el último tercio del Setecientos la Corporación había tomado otra iniciativa.

Tras 1771 la Academia había hecho ya un Diccionario, la Ortografía y la Gramática, y entonces —nos informa otra vez Cotarelo-

volvió la vista, aunque nunca la había apartado por completo, a otro de los mandatos de su primitivo estatuto, que era no sólo el estudio téc- 
nico del idioma sino el de los elementos estéticos del mismo cuando, puesto en acción y ejercicio, produce obras bellas de palabra hablada o por escrito. La elocuencia y la poesía, el cultivo, fomento y desarrollo de estas dos artes fueron siempre anhelo de la Academia.

En cuanto a la elocuencia tal objeto tenían desde luego también las disertaciones mensuales de académicos, los elogios a la muerte de algunos de ellos, etc.; el fomento de la poesía llevó a su vez al establecimiento de premios en concurso público, como es bien sabido; María José Rodríguez Sánchez de León ha empezado a estudiar tales premios en relación con la preceptiva de la época ${ }^{3}$. A modo de mera llamada de atención sobre el asunto podemos recordar la "Sátira contra los vicios introducidos en la poesía castellana» de don Leandro Fernández de Moratín, de 1792 y corregida luego en 1825, Sátira o Lección poética que han editado respectivamente John Dowling y Jesús Pérez Magallón, y que por ejemplo termina los tercetos que se ocupan de la poesía lírica desestimando a los autores que inventan «un idioma a su talante»:

Despreciando de Laso la cultura,

Con ceño magistral y agrio desvío,

Habla erizada jerigonza oscura,

$Y$ en gálica sintaxis mezcla voces

De añeja y desusada catadura,

Copiando de las obras que conoces

Aquella molestísima reata

De frases y metáforas feroces.

Con ella se confunde y desbarata

La hispana lengua, rica y elegante,

$Y$ a Benengeli el más cerril maltrata.

Cualquiera escritorcillo petulante

Licencia tiene, sin saber el nuestro[,]

De inventar un idioma a su talante,

3 «Estos premios - anota don Emilio Cotarelo- fueron tomando con el tiempo un carácter más útil y más inmediatamente provechoso para las tareas de la Academia, convirtiéndose en vocabularios y gramáticas especiales de la lengua usada por escritores famosos, y en estudios biográficos y críticos de tales escritoresm. Vemos así que la Academia no ha considerado nunca ajena a sus propósitos la tarea de la Historia de la lengua, y no deja de extrañar por ello que una voz autorizada de la Corporación haya propuesto hace poco - si la referencia de prensa es exacta- abandonar esa «matraca» de la Historia del idioma; matraca es, de acuerdo con la definición de Casares, una 'importunación molesta'. Nosotros creemos que en las tareas académicas resultan imprescindibles, compatibles y beneficiosos el esfuerzo dedicado al trabajo con procedimientos informáticos y la tarea de conocimiento del hacerse del idioma español. 
Que él solo entiende; y ensartando diestro

Sílabas, ya es autor y gran poeta

Y de alumnos estúpido maestro.

Moratín escribe irónicamente y está en contra de la «jerigonza oscura» y de la «gálica sintaxis», así como de las series de expresiones y metáforas «feroces» que «desbaratan» la lengua española; los estudiosos deberán concretar y ejemplificar tales rasgos elocutivos empleados por sucesivos autores ante los que proclama Moratín otro ideal artístico: en particular el mencionado prof. Pérez Magallón anota cómo don Leandro hace frente ahora a los poetas de la escuela de Meléndez, nuevos culteranos que mezclaban arcaísmos y galicismos.

Versos de Quevedo aparecen reproducidos en su texto por Moratín, quien satiriza en efecto este lenguaje poético barroco:

Una dama tendrás, cosa es precisa;

Bellísima ha de ser, no tiene quite,

Y llamarásla Filis o Marfisa. [...]

Dila que el alma, ajena de reposo

Nada golfos de luz ardiente y pura,

En crespa tempestad del oro undoso.[...]

Di que su cielo, del cenit trasunto,

Dos soles ostentó por darte en ojos,

Que si se ponen, quedarás difunto. [...]

La boca celestial, que enciende amante

Relámpagos de risa carmesíes,

Alto asunto al poeta que la cante,

Hará que en su alabanza desvaríes,

Llamándola de amor ponzoña breve,

O madreperla hermosa de rubíes.

Pasajes de Quevedo y juegos fonéticos característicos de la lírica barroca comparecen irónicamente en la propia textura moratiniana, quien reclama así otro modo de elocución poética.

En fin otra ironía es la de llamar enseguida «escuela tan maldita» a la clasicista:

$Y$ di que venga un literato al uso,

Con su Luzán y el viejo estagirita,

Llamándote ridículo y confuso;

Que yo sabré con férula erudita

Hacerle que enmudezca arrepentido,

Por sectario de escuela tan maldita. 
Don Leandro piensa en realidad que la poesía barroquizante resulta confusa y ridícula, pero en el tono irónico de sus tercetos la que aparece como secta maldita es la que concuerda con el espíritu de Luzán. La Lección poética es uno de los documentos que acerca de los criterios de estilo ha de tener presente la Historia de la lengua; en su género - se ha dicho- parece una pieza maestra.

\section{LAS EMPRESAS ACADÉmICAS: EL DiCCIONARIO}

En 1715 aparecieron publicados - y luego están en las págs. XXIII y ss. del Tomo Primero del Diccionario de la lengua castellana o Diccionario de Autoridades - «los estatutos que su Magestad havía aprovado» al fundarse la Real Academia, que se inician por un «Estatuto Único» el cual proclama, si modernizamos la acentuación:

Siendo el fin principal de la fundación de esta Academia cultivar, y fijar la pureza y elegancia de la lengua Castellana, desterrando todos los errores que en sus vocablos, en sus modos de hablar, o en su construcción ha introducido la ignorancia, la vana afectación, el descuido, y la demasiada libertad de innovar: será su empleo distinguir los vocablos, phrases o construcciones extrangeras de las proprias, las antiquadas de las usadas, las baxas y rústicas de las Cortesanas y levantadas, las burlescas de las serias, y finalmente las proprias de las figuradas. En cuya conseqüencia tiene por conveniente dar principio desde luego por la formación de un Diccionario de la lengua, el más copioso que pudiera hacerse: en el qual se annotarán aquellas voces y phrases que están recibidas debidamente por el uso cortesano, y las que están antiquadas, como también las que fueren baxas, o bárbaras.

El libro primero que se propusieron los académicos era pues un Diccionario que fijase la lengua al desterrar los errores traídos no ya por la ignorancia o el descuido, sino asimismo por el deseo inmoderado de innovación y la afectación subsiguiente: se trataba de delimitar bien lo propio, es decir, lo castizo o patrimonial, y además se trataba de delimitar los niveles diastráticos y los registros del hablar de acuerdo con el uso de los autores clásicos y con el uso cortesano y actual del momento.

Refiriéndose a las mentes más despiertas de varios países europeos en los siglos XVII y XVIII, don Samuel Gili explicaba con claridad el afán de las Academias: 
Sentían que algo había cambiado entre la manera actual de expresarse y la de sus clásicos, y los cambios ya visibles producían alarma. De aquí nace el afán de fijación y norma que en los países latinos representan las Academias. [...] Eran buenas las palabras que se hallaban autorizadas en los textos de los escritores considerados en cada país como clásicos.

En realidad los académicos españoles de 1715 mantenían un criterio casticista que estuviese atento asimismo al uso cortesano y a los diferentes registros del hablar.

Los presentes primeros estatutos de la Real Academia establecían también otro designio, junto con el del Diccionario o libro fundamental acerca del idioma:

Fenecido el Diccionario ([...] primer objeto de la Academia) se trabajará en una Grammática, y una Poética Españolas, e Historia de la lengua, por la falta que hacen en España. Y en quanto a la Rhetórica podrá excusarse de trabajar de nuevo, porque hai bastante escrito.

Se anuncia así el propósito de una Gramática, que realmente tardó más de medio siglo en aparecer según queda dicho.

Menéndez Pelayo valoró el papel filológico que venía a cumplir la Academia y el sólo indirectamente crítico-estético que tuvo; en realidad la Corporación limpiaba y en consecuencia fijaba el idioma, aun entre tanteos y la vigencia muy actuante de las letras de todo el Seiscientos. Don Marcelino en particular concretaba así su interpretación:

Fundada [la Academia] sobre todo para hacer el inventario de la lengua, para depurarla [...] de los vicios que un siglo de decadencia literaria la había legado, y para poner un dique a la invasión ya temible del galicismo, su misión fue y tenía que ser filológica más bien que crítica ni estética, y sólo de un modo muy remoto podía influir en la dirección del gusto de prosistas y poetas. [...] Procedió con criterio tan ancho y aun con gusto tan inseguro, que lo que más asombra en nuestro gran Diccionario vulgarmente llamado de autoridades, es el copioso número de ejemplos algunos de ellos bien extravagantes, tomados de los escritores más culteranos, más conceptistas y más equivoquistas.

Ciertamente hemos de entender que el Diccionario de 1726 se proponía limpiar y así dar esplendor a las palabras, con lo que quedaban fijadas en ese esplendor castizo; el gusto era aún inseguro, y entre otras cosas quizá se eli- 
minaron las autoridades del Diccionario en 1780 porque a tal altura se poseía ya un criterio de gusto más lejano al del siglo XVII.

Por su lado el «Prólogo» del Tomo Primero del Diccionario de Autoridades, antes de que en tal tomo estuviesen transcritos los primeros estatutos de 1715 (que si los contamos vemos que eran treinta y cinco), había proclamado ya el propósito de la entonces naciente Corporación:

El principal fin -dice este «Prólogo»- que tuvo la Real Academia Española para su formación, fue hacer un Diccionario copioso y exacto en que se viesse la grandeza y poder de la Lengua, la hermosura y fecundidad de sus voces, y que ninguna otra la excede en elegancia, phrases, y pureza: siendo capaz de expressarse en ella con la mayor energía todo lo que se pudiere hacer con las Lenguas más principales, en que han florecido las Ciencias y Artes.

El presente párrafo no es de carácter fundamentalmente técnico como lo es el del «Estatuto Único» que ya hemos considerado, sino que lleva en sí un tono emocional y diríamos que protonacionalista: trataba de encarecer el poder comunicativo del idioma patrimonial para no importa qué ciencias 0 artes.

Asimismo declara la Corporación cuál es el subgénero literario de la empresa que acomete: se trata de un «diccionario» y no de un «vocabulario», de acuerdo con un deslinde de significaciones que establece de manera expresa (modernizamos a veces la acentuación):

En la Lengua Española se entienden comunmente por Vocabularios los libros en que se expressan las voces, sin explicarlas, ni adornarlas con etymologías y phrases que se vuelven en otra Lengua como Latina, Francesa, o Toscana, y por Diccionarios se entienden los libros, donde no sólo se vierten en otra Lengua los vocablos, sino que se explica su naturaleza, y el sentido de las phrases, quando la voz se junta con otra, u otras.

El Diccionario de la lengua castellana estaba atento en efecto la naturaleza de las voces y a la significación de las expresiones, y ello afianzado por la autoridad idiomática de los textos que avalaban así tanto el léxico usual y conocido como el que ya no se encontraba en uso.

La Real Academia surgía a principios del Setecientos - se dice asimismo en el presente «Prólogo»— no para enmendar lo lingüístico patrimonial sino para corregir los abusos a los que se había llegado: se trataba de limpiar la lengua; 
Los Diccionarios de las Lenguas - manifiestan los primeros académicos- $[$...] expressan los significados de las voces, su variedad, el sentido de cada una, sus phrases y elegancia [..., y faltándole a la Lengua Española el suyo, ha sido este el principal empeño de la Academia, sin que sea su fin emendar ni corregir la Lengua [..., y] sí sólo explicar las voces, phrases, y locuciones, desterrar y dar a conocer los abusos introducidos, para lo qual no ha omitido explicar muchas voces antiquadas, algunas que tienen ya menos uso, y calificar la energía y elegancia de la Lengua, assí para el uso de los extrangeros como para curiosidad de la Nación.

Explicar las voces y desterrar los abusos en su empleo constituía el doble objetivo complementario del Diccionario académico y aun del empeño todo emprendido por la Corporación; quedaba limpio así el idioma, y fijado ante la propia comunidad política y cultural y ante los extranjeros. Los académicos encarecían a la vez el gran trabajo llevado a cabo y su necesaria imperfección («una obra tan grande como la del Diccionario no puede salir de una vez con toda la perfección que debe por el immenso trabajo que ha costado el hallar las voces, sus significados, y las autoridades que corresponden a cada una: y assí es preciso que se noten muchos defectos").

En cuanto al diseño y «planta» del Diccionario de la lengua castellana o Diccionario de Autoridades el propio «Prólogo» lo anuncia (sintetizamos nosotros esquemáticamente):

a) «En este Diccionario se ponen generalmente todas las voces de la Lengua, estén, o no en uso, con algunas pertenecientes a las Artes y Ciencias».

b) En efecto «de las voces proprias pertenecientes a Artes liberales y mechánicas [...] se ponen sólo las que han parecido más comunes y precisas al uso, y que se podían echar menos».

c) «Se ponen varias voces peculiares y proprias, que se usan frequentemente en algunas provincias y reinos de España, como en Aragón, Andalucía, Asturias, Murcia, \&c. [,] aunque no son comunes en Castilla.

d) «También se annotan las voces de la Gerigonza o Germanía, de que suelen usar los que vulgarmente se llaman Gitanos, y los preciados de guapos para entenderse entre sím.

e) «Los synónymos que se ponen en este Diccionario, para declarar e ilustrar las voces, son pocos; pero los más escogidos, semejantes, e immediatos al significado, porque bien examinada la energía de la Lengua Española, son mui limitados los synónymos que en ella corresponden enteramente: y assí se ha determinado omitirlos, no haciendo falta para la explicación de las voces, y sólo se expressan los que no admiten duda en lo conforme de la significación». 
f) «Han quedado excluídas del Diccionario todas las voces y nombres proprios de personas y lugares».

g) «Se han excusado también todas las palabras que significan desnudamente objeto indecente».

h) «En cada voz se explica la parte que es de la oración, si verbo, nombre, o participio, \&c. [,] con la advertencia de haver puesto en los verbos los tiempos que tienen irregulares: como en andar, anduve».

Tenemos así un diseño o "planta» del Diccionario que da lugar a los rasgos que caracterizan su pertenencia a un género o subgénero literario: el subgénero «diccionario» - proclamaban sus autores- y no el de «vocabulario»; la trayectoria posterior del Diccionario de Autoridades primero en un primer tomo de su proyectada segunda edición y luego en el Diccionario común o $D R A E$, supone justamente el cumplimiento de la trayectoria de un género literario, en la cual los rasgos compositivos se repiten tales cuales o bien en variante.

Don Samuel Gili subrayó en su día algo que por lo demás es muy evidente: las «autoridades» que respaldaban a cada palabra y sus acepciones habían sido escogidas con amplitud de criterio (a Menéndez Pelayo le parecía más bien que a veces con desorientación de criterio), quedando fuera sólo - según observa Gili- los líricos postgongorinos o también «el gerundianismo alocado en el púlpito». Por igual se estimó que garantizaban la patrimonialidad tradicional de los vocablos «autoridades» como los textos del romancero, el refranero, etc.

EN FAVOR DE LA FILOLOGIA Y DEL ESTUdIO DE TODO EL PASADO ESPAÑOL

Hemos apuntado s6́lo algún asunto de los que ha de ocuparse la Historia de la lengua, y hemos subrayado -como otras veces- la importancia de no desatender lo posterior a 1681, pues hasta entonces llega el panorama global trazado por don Ramón Menéndez Pidal en su obra inacabada y sólo editada todavía en parte *Historia de la lengua española.

Cada día estamos más persuadidos de que junto a los estudiosos bastante especializados que se ocupan por ejemplo de la fonología histórica de la lengua (Alarcos) o de su morfología (Alvar y Pottier), ..., hacen falta otros filólogos que lean con regularidad y en número importante las obras literarias y las preceptivas literarias castellanas, los textos que testimonian la trayectoria de las ideas lingüísticas entre nosotros, etc., pues sólo conociendo estas fuentes será posible llegar a conocer algunos hechos ciertos y de relieve en la historia del idioma. 
Por ejemplo y además, en lexicografía y para el estudio del léxico se han empezado a emplear ya y se emplearán crecientemente los instrumentos informáticos: en verdad resultan imprescindibles porque dan seguridad a muchos datos y ahorran esfuerzos muy penosos y lentos, pero la revisión humana y con criterio filológico de todo lo que nos dé hecho el ordenador resulta absolutamente imprescindible.

En lo psicológico cuesta mucho atender a lo no atendido antes, como puede ser nuestro Ochocientos y el primer tercio del siglo presente, pero también resulta necesario hacerlo; se entiende que el filólogo se halle prendado de algunos textos de Garcilaso por ejemplo, o de los de la lírica tradicional asimismo por ejemplo, pero el análisis de todas las centurias en la historia de nuestra lengua y de los más diversos fenómenos que aparecen en todas y cada una de las épocas que distingamos en la misma resulta — según decimos- necesario en buena lógica investigadora.

Las fuentes acerca de la trayectoria del idioma a partir del Ochocientos abundan mucho, y no se encuentran en el mercado como por ejemplo podemos disponer con comodidad de muchos textos lopeveguescos, de Quevedo, ...; el esfuerzo en la identificación primero y en la búsqueda luego de estas fuentes no ha de ser tampoco pequeño: analizar la lengua literaria, las ideas lingüísticas o la preceptiva literaria de por ejemplo nuestro Ochocientos no es lo mismo que comentar un cuento de don Juan Manuel, una égloga de Garcilaso o cualquier soneto de la literatura clásica, y quizá porque estamos menos habituados y por el esfuerzo previo que supone de búsqueda de fuentes, es una tarea menos llevada a cabo.

Las publicaciones de Rafael Lapesa permiten completar en buena medida -si exceptuamos los años que van desde hacia 1843 hasta 1898 -, la Historia de la lengua trazada por don Ramón, pero por ejemplo la trayectoria de las ideas estético-literarios en todo el «siglo» liberal español es aún bastante poco conocida, si no nos engañamos: hay alguna buena monografía, pero tenemos la sensación de que a Menéndez Pelayo, a Menéndez Pidal, a Guillermo de Torre, a don Dámaso y a José Fernández Montesinos, a Emilio Orozco y a José Antonio Maravall (en lo que nos importa ahora), no se les lee mucho.

En dos palabras, que queremos hacer llegar a nuestros alumnos de la Universidad Nacional de Educación a Distancia: estudiemos la Edad Media y la Alta Edad Moderna, pero a la vez, sumando y no restando, la Baja Edad Moderna y la Edad Contemporánea. Lo estrictamente actual suele tenerse muy presente y se lee y se analiza, pero la densidad de lo contemporáneo no actual no debería escapársenos.

Hagamos pues una apuesta en favor de lo filológico, y en favor asimismo del todo completo del pasado de nuestra cultura y de nuestra filología. 